\title{
A Trial for Curriculum Development: The Effect of Educational Philosophy Curriculum on the Attitudes towards Course and Educational Views *
}

\author{
Orhan Kumral \\ Correspondence: Orhan Kumral, PhD, Pamukkale University, Faculty of Education, Denizli-Turkey
}

Received: January 21, 2016

Accepted: February 14, 2016 Online Published: February 16, 2016

doi:10.11114/jets.v4i3.1384

URL: http://dx.doi.org/10.11114/jets.v4i3.1384

\begin{abstract}
In Turkey, Educational Philosophy is a compulsory course for the students of education faculties, which serve the purpose of training the teachers of future generations. Furthermore, in some other programs, students are able to take the course as an elective course. The continuous changes in culture, science, and technology force the curriculum of all courses to be renovated, as in the situation of Educational Philosophy. The current study aims (1) to design a new curriculum for the course of Educational Philosophy, and determine the effect of this design on (2) student attitudes towards the course and (3) the perceptions about educational viewpoints and practices. In the current study, the Taba Model, one of the curriculum development models, was used during the preparation process of the draft. For the evaluation process of the curriculum design, single group pre- and post-test design as one of the quantitative methods was conducted. The Educational Philosophy course was developed through adopting a student-centred design and using the Taba Model. As the result of the curriculum implementation, it was concluded that: (1) The curriculum designed for the study changed the attitudes of learners significantly and positively (2) The curriculum designed for the study decreased the anxiety of the learners towards the course significantly and positively, (3) The curriculum designed for the study changed the beliefs of the learners significantly and positively that they would use these common course standards in their teaching, (4) The curriculum designed for the study made the participant learners get out of traditional [Positivist-Modern] subject- or teacher-centred educational philosophy, (5) The curriculum designed for the study made the participants be familiar with the learner-centred popular-modern [Constructivist] educational philosophy.
\end{abstract}

Keywords: curriculum development, educational philosophy, Taba Model

\section{Introduction}

Scientific and technological development and social changes require more qualified labour force in the current era. Training qualified people or people that are able to adapt changes are possible through education. However without an intervention to curriculum, which is an important component of education process, such change-oriented, qualified people cannot be educated. For this reason, there is a need for development of curriculums. However, "development curriculum is not to determine courses in a particular school system, their distribution of weeks and months; it is not to replace a course with another or to make some changes in content, to reduce or increase its duration" (Sönmez, 2009: 441).

According to Tyler, (2013: 271), "curriculum development is not a theoretical but a practical study and it is not an attempt to explain a basic phenomenon but to design a system for an educational purpose". According to Varış (1996: 16) curriculum development "is development of a curriculum by a researcher in practice". The aim in this process is not to change curriculum but to train more qualified people with regard to all school processes ranging from student properties to physical conditions of schools and from teachers to other employees."

There are many interactive factors during education process. Therefore, it is necessary for education workers to consider

\footnotetext{
* This study was presented orally on the 3rd International Congress on Curriculum and Instruction (ICCI-2015) thanks to Pamukkale University BAP Unit's financial support. The study was developed in the light of evaluations.
} 
several and interrelated factors concerning causes, effects and suggestions; they need to handle this issue with an analytical approach. For this reason, a scientific approach is needed to order and develop educational institutions and educational practices in accordance with contemporary conditions. In this process, it is a matter of answering questions of Where? What? How? With what? How long to develop? About individual features; accordingly, the issue of curriculum development is constant development of outputs in education (Varış, 1996). "Attempts for curriculum development in some countries of Europe have been considered as an ordinary stage of education process; whereas in many countries including United States it is operated under the slogan of education reform. Countries such as Denmark, Sweden and Norway began to do research on curriculum development in the 1940s. They were able to achieve a relatively settled understanding of curriculum after experimental stages. It is observed that two thirds of the researchers conducted at Swedish universities in 1973-74 are about curriculum" (Demirel, 2012: 15).

According to Taba (1962), at the initial stages of curriculum development process and after several needs analyses, goals are determined in order to satisfy student needs; these goals are supposed to be compatible with student's development features and data concerning educational psychology. Next, the content that how these goals are attributed desired type of subjects and disciplines, educational situations in which techniques and methods to discuss this content and testing situations, which demonstrates the level of development of education within or in the end of this process, are formed. This process reveals four main components of curriculum. In this sense, curriculum development can be defined as "a dynamic whole of relations between the components of goal, content, learning-teaching process and assessment of curriculum" (Demirel, 2012: 5). The change and development of one or more of these four components would result in change of others.

According to Tyler (2013: 284) "if students are not able to transfer their teachings to their lives outside of school, then education is a failure. Generally educators and administrators tend to ignore this important point". Changes in culture, science and technology and other fields outside of school life bring the need for curriculums at schools that are necessary to reflect these changes to students or these changes might cause obligatory changes in course of curriculums. In this context, curriculum development efforts are vitally important at all educational institutions, however development of curriculums at institutions where teachers are trained might be considered more important.

This situation might reflect on Educational Philosophy course, which is taught as a selective or compulsory course for teacher candidates at some education faculties. Because, according to Gosselin (2007) and Winc (2012), conceptual discussions on education philosophy and educational process help teachers in understanding their studies and following their own paths. Without educational philosophy, it is very difficult for candidate teachers to comprehend their practices during educational process. "Educational philosophy enlightens the ideas that support actions and thoughts in education. Philosophers' questions are about the nature and purposes of education: What makes a person educated, how is knowledge classified and what is to be taught?" (Bartlett and Burton, 2014: 25). According to Orstain and Hunkins (1988), philosophy presents a basic framework to educators and particularly to curriculum developers in order to regulate schools and classes. It helps to understand the purpose of schools, which courses are important and what type of tools and methods are employed. Educational Philosophy as a course plays an important role for teachers in early stages of teaching and after.

According to Weber, 1998: 2) all sciences need philosophy to free from being a non-living body. In this context, philosophy gives the soul to science. As education is a scientific process (Aydın, 2012; Bartlett and Burton, 2014; Murphy, Mufti and Kassem, 2009; Osler, 2013; Yüksel, 2012; Zierer, 2009), it also needs philosophy. The question "why education?" and answers that are sought for this question brings a philosophical process and in other sense a soul to education (Kumral, 2015: 74). Philosophical practices on education constitute basis of educational theory, policy, practice and research fields (Bartlett and Burton, 2014; Oancea and Bridges, 2009). The most significant course demonstration the collaboration between philosophy and education seems to be the Educational Philosophy course.

Particularly since 2005, a changing paradigm appears in the Turkish Education System. The Educational Philosophy course seems to play a key role in settlement of this paradigm because teacher candidates can understand this paradigm only through philosophical bases. The Educational Philosophy course might accomplish this expected role with the help of curriculum development.

The aims of this research are:

(a) to develop a new curriculum towards the Educational Philosophy course and in line with changing paradigm (b) to demonstrate effects of this design on teacher candidates' attitudes towards courses (c) and their educational opinions.

\section{Method}

\subsection{Research Model and Curriculum Design Approach}

The study employed the Taba Model in curriculum development process. In assessing curriculum design, the study 
benefited from pre-test post-test one sample model as a qualitative method (Karasar, 1995: 96). The symbolic representation of the model is presented on Table 1.

Table 1. Pre-test post-test one sample model

$$
\begin{array}{llll}
\mathrm{G}_{1} & \mathrm{O}_{1} & \mathrm{X} & \mathrm{O}_{1}
\end{array}
$$

The Educational Philosophy course curriculum was designed as learner-centred and formed through the Taba Model. Hilda Taba's model consists of eight stages (Taba, 1962: 347-379). The stages that are required to follow in development of each unit are the following: Step One: Diagnosing Needs, Step Two: Formulating Specific Objectives, Step Three: Selecting Content, Step Four: Organizing Content, Steps Five and Six: Selecting and Organizing Learning Experiences, Step Seven: Evaluating and Step Eight: Checking for Balance and Sequence.

The curriculum, which was designed according to the Taba Model, was prepared in line with the Learner-Centred Curriculum Design approach (Demirel, 2012: 47). In this design, learners' need about the course and satisfaction of these needs were considered important rather than teaching style of subjects. In regulating content, the question-centred curriculum approach (Demirel, 2012: 129) was employed. "In the context of curriculum design, main framework of a curriculum is attempted to form and answers are sought for these four questions: (1) What has to be done? (2) What should the content include? (3) What type of learning strategies, sources and activities should be used? (4) What sort of measurement techniques and tools are to be used in order to evaluate results? All curriculum designs are supposed to contain all these four components" (Demirel, 2012: 44). This study attempted to form these four above-mentioned components. In doing so, first a study plan was designed. The summary of study plan, which was prepared in accordance with the Taba Model, and process/time chart is presented below (Chart 1).

\begin{tabular}{|c|c|c|c|c|c|c|c|c|c|c|c|c|c|c|c|c|c|c|c|c|c|}
\hline \multirow{2}{*}{$\overbrace{\text { Time }}^{\text {Process }}$} & \multicolumn{4}{|c|}{ September } & \multicolumn{4}{|c|}{ October } & \multicolumn{4}{|c|}{ November } & \multicolumn{5}{|c|}{ December } & \multicolumn{4}{|c|}{ January } \\
\hline & 1 & 2 & 3 & 4 & 1 & 2 & 3 & 4 & 1 & 2 & 3 & 4 & 1 & 2 & 3 & 4 & & 1 & & 3 & 4 \\
\hline Determination of field of study & $\mathrm{X}$ & $\mathrm{X}$ & & & & & & & & & & & & & & & & & & & \\
\hline Planning & & $\mathbf{X}$ & $\mathbf{X}$ & & & & & & & & & & & & & & & & & & \\
\hline Needs Analysis & & & $\mathbf{X}$ & $\mathbf{X}$ & $\mathbf{X}$ & & & & & & & & & & & & & & & & \\
\hline Goal Statement & & & & & $\mathbf{X}$ & $\mathbf{X}$ & $\mathbf{X}$ & & & & & & & & & & & & & & \\
\hline Regulation of the content & & & & & & $\mathbf{X}$ & $\mathbf{X}$ & $\mathbf{X}$ & $\mathbf{X}$ & $\mathbf{X}$ & & & & & & & & & & & \\
\hline $\begin{array}{l}\text { Preparation of Table of } \\
\text { Specifications }\end{array}$ & & & & & & & $\mathbf{X}$ & $\mathbf{X}$ & $\mathbf{X}$ & $\mathbf{X}$ & $\mathbf{X}$ & $\mathbf{X}$ & $\mathbf{X}$ & & & & & & & & \\
\hline Regulation of Education Status & & & & & & & & & $\mathbf{X}$ & $\mathbf{X}$ & $\mathbf{X}$ & $\mathbf{X}$ & $\mathbf{X}$ & $\mathbf{X}$ & & & & & & & \\
\hline Preparation of Test Items & & & & & & & & & & & & & & & & & & $\mathbf{X}$ & $\mathbf{X}$ & $\mathbf{X}$ & \\
\hline Process & & Feb & uary & & & $\mathrm{Ma}$ & arch & & & & pril & & & & May & & & & Jun & ne & \\
\hline IIIII & 1 & 2 & 3 & 4 & 1 & 2 & 3 & 4 & 1 & 2 & 3 & 4 & 1 & 2 & 3 & 4 & & 1 & 2 & 3 & 4 \\
\hline Employment of Test & & & $\mathbf{X}$ & $\mathbf{X}$ & & & & & & & & & & & & & & & & & \\
\hline Measurement of Attitudes & & & $\mathbf{X}$ & $\mathbf{X}$ & & & & & & & & & & & & & & & & & \\
\hline Application of Program & & & $\mathbf{X}$ & $\mathbf{X}$ & $\mathbf{X}$ & $\mathbf{X}$ & $\mathbf{X}$ & $\mathbf{X}$ & $\mathbf{X}$ & $\mathbf{X}$ & $\mathbf{X}$ & $\mathbf{X}$ & $\mathbf{X}$ & $\mathbf{X}$ & $\mathbf{X}$ & & & & & & \\
\hline Employment of the Last Test & & & & & & & & & & & & & & $\mathbf{X}$ & $\mathbf{X}$ & & & & & & \\
\hline Measurement of Attitudes & & & & & & & & & & & & & & $\mathbf{X}$ & $\mathbf{X}$ & & & & & & \\
\hline Analysis of Measures & & & & & & & & & & & & & & & $\mathbf{X}$ & $\mathbf{X}$ & & $\mathbf{X}$ & $\mathbf{X}$ & $\mathbf{X}$ & \\
\hline Reporting & & & & & & & & & & & & & $\mathbf{X}$ & $x$ & $\mathbf{x}$ & $\mathbf{x}$ & & $\mathbf{X}$ & $\mathbf{X}$ & $\mathbf{X}$ & $\mathbf{X}$ \\
\hline
\end{tabular}

Chart 1. Proceeding- Time Chart

\subsection{Participants of the Research}

Participants of the research consist of 112 teacher candidates, who were voluntarily selected from hundred and seventy-six students in four sections that took the Educational Philosophy course and studied at Pamukkale University, Faculty of Education, and Department of Classroom Teaching during 2014-2015 academic year. As participants from 
each section had different features such as number of participants, gender and academic achievement, the study was conducted with the help of single group pre-test post-test model instead of a study design with a control group.

\subsection{Data Collection Tools}

During the needs analysis process, which was conducted to achieve the first aim of the study, student that took the relevant course $(n=82)$ received a structured form for qualitative data in order to formulate a document concerning the needs. This form consisted of 3 basic questions: (1) What were your expectations from the Educational Philosophy course? (2) Which expectations were satisfied? Why? (3) Which expectations were not satisfied? Why?

In order to achieve the last two goals of the research, two scales were used as data collecting tools. The first one is the attitude scale towards the course, which was developed by the researcher to demonstrate curriculum-oriented differences. The Education Philosophy Course Attitude Scale consists of 14 questions. It has three sub-dimensions: anxiety, professional contribution and interest. Total reliability of the scale was found $\alpha=.88$, reliability of sub-dimension of anxiety was $\alpha=.77$, reliability of sub-dimension of professional contribution was $\alpha=.64$ and reliability of sub-dimension of interest to the course was $\alpha=.79$. The other scale is Educational Opinions and Practices Scale (EDU), which are used for participants' expression of their educational philosophy.

EDU scale aims to make sense of teachers' or teacher candidates' opinions about education process and philosophically attribute meanings to their operational thoughts. Exploratory and confirmative factor analyses of the scale were conducted; it is a reliable scale. In exploratory factor analysis consisting of 42 questions, two dimensions appeared. It was observed that these two dimensions explained $61,533 \%$ of the total variance. The lowest difference between factor loads of the question was above .55. As the lowest difference between factor loads of the questions was suggested .10 (Büyüköztürk, 2006, 125), it can be said that questions were distributed in accordance with the factors on the scale. The researched called these dimensions "Traditional" and "Popular" with regard to the relevant literature.

Traditional subscale demonstrates that opinions and practices are mostly created through a realist understanding and Perennial and Essentialist educational philosophy. Popular subscale, however, considers that opinions and practices of education process are mostly created through Pragmatic, Existentialist and Constructivist understanding and Progressive and Re-Constructivist educational philosophy. It is observed that the lowest factor load of questions at each factor is over .50. According to Büyüköztürk (2006), load values of factors over .45 is a sufficient criterion for selection. At the same time, it is seen that the variance that is explained by both factors has enough percentage to explain whole of scale. For Confirmative Factor Analysis of 42 questions, $\chi^{2}$ (chi-square) value was found significant $\left(\chi^{2}=1665,08 ; p<.01\right.$ ), degree of freedom (df) was found 818 . The ratio of these values is the following: $\chi^{2} / \mathrm{df}=2,03$. Other fit index data are the following: $\mathrm{RMSEA}=.062, \mathrm{NFI}=.97, \mathrm{CFI}=.98, \mathrm{SRMR}=.048, \mathrm{GFI}=.85, \mathrm{AGFI}=.83$. EDU Scale of 42 questions has structural validity and scale reliability that enables to demonstrate opinions and practices of educators as "Traditional" and "Popular" (Kumral, 2014).

Data analyses of this current research found put the correlation between subscales as $-74 \mathrm{p}=.000(\mathrm{n}=112)$. Similarly, data analyses of this current research found out that reliability coefficients of the scale were the following: value for Traditional subscale $\alpha=.89(\mathrm{n}=112)$ and value for Popular subscale $\alpha=.89(\mathrm{n}=112)$. In this sense, the scale has structural validity, as participants' tendency towards Traditional or Popular educational philosophies and $\alpha$ coefficients indicate that the scale is reliable.

\subsection{Data Analysis}

In analysing qualitative data for identification of needs, descriptive method was employed. For analyses of quantitative data, firstly normality of distribution of variables was examined. As there were more than 50 participants, Kolmogorov-Smirnov normality test (Seçer, 2013: 25; Büyüköztürk, 2006: 42) demonstrated that the distribution was normal. For this reason, parametric analyses were conducted on quantitative data.

\section{Results}

Research results that drew from data analyses, aims of the research, the curriculum design approach that is used in this research, process-time chart that is mentioned on methodology section are presented below.

\subsection{Determination of Field of Study, Planning and Needs Analysis}

Course content of the Education Philosophy course for 2006 was examined (YÖK, 2007: 33). This course, which is considered as general knowledge course at YÖK curriculum, is taught as a professional course at faculties of education under the title of Educational Philosophy. As it is called in the literature, the Educational Philosophy course has been considered as a significant course for definition of school by teacher candidates, foundation of their duties and responsibilities and making sense of practices during education process.

The development of the Educational Philosophy course was needed for teacher candidates, who are supposed to execute 
curriculums of primary and secondary education institutions that have been structured in accordance with the changing learner's paradigm. The planning was made in line with the Taba Curriculum Development Model; so that teacher candidates are expected to resolve philosophical bases of their curriculum.

\subsection{Determination of Needs for the Course}

Needs for the course were determined by Descriptive Analysis, which is among needs analysis approaches and by document analysis techique, which is one of needs analysis techniques. In order to create a document towards needs concerning the Educational Philosophy course, takers of this course in previous years $(n=82)$ were distributed a structured form. This form consisted of three basic questions: (1) What were your expectations from the Educational Philosophy course? (2) Which expectations were satisfied? Why? (3) Which expectations were not satisfied? Why?

The structured form was analysed through the descriptive analysis method. Research findings were categorised into themes. The needs were observed to be concentrated in these themes:

(1) Demonstration of the significance of philosophy and educational philosophy approaches and their concrete outputs in terms of education process rather than definition of these approaches

(2) Learners' awareness of their educational philosophy

(3) Learners' development of a perspective towards their possible educational environment when they become teachers In the light of these needs, gains of the course were identified.

\subsection{Setting Goals}

It was observed that gains were concentrated on cognitive and affective domains. On cognitive domain, goals were set to satisfy learning needs of students that were revealed by needs analysis; it is associated with the "analysis" stage. Goals on affective domain are associated with promotion of students, who took the Educational Philosophy course, to the "value attribution" stage. The design includes 47 goals that a teacher candidate:

1. Knows about the fields of philosophy, science and religion.

2. Comprehends the relationship between philosophy and sciences.

3. Analyses education as a science on ontological and epistemological bases.

4. Explains the relationship between philosophy and education.

5- Knows about fields of philosophy.

6- Knows about schools of philosophy.

7- Knows about schools of educational philosophy.

8- Explains the relationship between schools of philosophy and schools of educational philosophy.

9- Gives examples of bases of an educational philosophy and its representations on an educational environment.

10- Analyses an educational environment from a perspective of a particular educational philosophy.

11- Notices that all education process depends on a philosophy.

12- Shows interest in designing an original educational environment that is compatible with educational philosophy.

13- Knows about curriculum design models.

14- Comprehends the relationship between curriculum design and educational philosophy

15- Explains educational philosophy influencing a design sample.

16- Knows about components of curriculum.

17- Explains how components of curriculum are affected by educational philosophy.

18- Analyses components of curriculum through educational philosophy that affects it.

19- Analyses curriculum that he or she receives in terms of schools of philosophy and educational philosophy.

20- Analyses education systems of countries in terms of social life and philosophy of these countries.

21- Is aware of how order of seating affects students during education process.

22- Notices about the impacts of student-teacher relations on student life during education process.

23- Notices about the impacts of teachers' methods and techniques on students during education process.

24- Is willing to participate analysis efforts concerning the impacts of education environments on himself. 
25- Analyses the impacts of education environments on himself.

26- Establishes relationship between educational strategy, methods and techniques and teacher's educational philosophy.

27- Establishes relationship between order of seating in classroom and teacher's educational philosophy.

28- Establishes relationship between classroom environment and teacher's educational philosophy.

29- Is willing to create education environments in accordance with his or her educational philosophy.

30- Remembers basic knowledge about behavioural learning theory.

31- Analyses epistemological bases of behavioural learning theory.

32- Remembers basic knowledge about cognitive learning theory.

33- Analyses epistemological bases of cognitive learning theory.

34- Has knowledge on constructivist paradigm.

35- Explains constructivism as a learning theory.

36- Establishes relationship between constructivist learning and schools of pragmatism and progressivism.

37- Gives examples about the social role of school.

38- Classifies school according to its social role.

39- Is willing to design a school that he or she wants to work.

40- Designs a new school model.

41- Explains how education would be possible in a society without schools.

42- Analyses schools of philosophy that education might depend in a society without schools.

43- Analyses educational structure during Seljuk and Ottoman period on the basis of schools of philosophy.

44- Analyses the structure of education in turkey on the basis of philosophical approaches and in the context of types of schools that he or she studied, courses and curriculums.

45- Is aware of critical attitudes towards education process.

46- Critically evaluates his or her education.

47- Appreciates educational discussion about the ideal education process.

\subsection{Selection and ordering of the content}

The subjects to be benefited to achieve goals consisted of eight units and two basic themes "education process needs philosophy" and "critical pedagogy". It was observed the subjects consisted of units, which were about analytical thinking of learners and their satisfaction of learning expectations in a more analytical way. The content was presented below with its themes, units, subject and sub-topics. In addition, tables of specifications helped to establish relationship between goals and subjects.

THEME 1: Education Process Needs Philosophy

Goals:

1. Knows about the fields of philosophy, science and religion.

2. Comprehends the relationship between philosophy and sciences.

3. Analyses education as a science on ontological and epistemological bases.

4. Explains the relationship between philosophy and education.

Unit 1: Philosophy-Science and Religion

Philosophy, science and religion on the basis of their pursuits.

Is education a science?

The relationship between education and philosophy. 
Table 2. Unit 1 table of specification

\begin{tabular}{|c|c|c|c|c|}
\hline \multirow{2}{*}{ SUBJECT } & \multicolumn{3}{|c|}{$\begin{array}{c}\text { COGNITIVE } \\
\text { DOMAIN }\end{array}$} & \multirow[b]{2}{*}{ Total } \\
\hline & 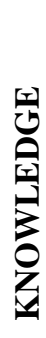 & 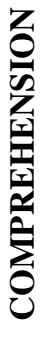 & $\begin{array}{l}\frac{\mathscr{2}}{2} \\
\frac{\pi}{3} \\
\frac{\pi}{Z}\end{array}$ & \\
\hline Pursuits of philosophy, science and religion & 1 & & & 1 \\
\hline The relationships between philosophy, science and religion & & 1 & & 1 \\
\hline Education as a science & & & 1 & 1 \\
\hline The relationship between philosophy and education & & 1 & & 1 \\
\hline Total & 1 & 2 & 1 & 4 \\
\hline
\end{tabular}

Goals:

1- Knows about fields of philosophy.

2- Knows about schools of philosophy.

3- Knows about schools of Educational Philosophy.

4- Explains the relationship between schools of philosophy and schools of educational philosophy.

5- Gives examples of bases of an educational philosophy and its representations on an educational environment.

6- Analyses an educational environment from a perspective of a particular educational philosophy.

7 - Notices that all education process depends on a philosophy.

8- Shows interest in designing an original educational environment that is compatible with educational philosophy.

Unit 2: Domains of Philosophy and Educational Philosophy

Domains of Philosophy

Ontology and Epistemology

Schools of Philosophy

Realism - Pragmatism and Existentialism

Schools of Educational Philosophy

Perennialism-Essentialism-Progressivism and Re-Constructivism

Table 3. Unit 2 table of specification

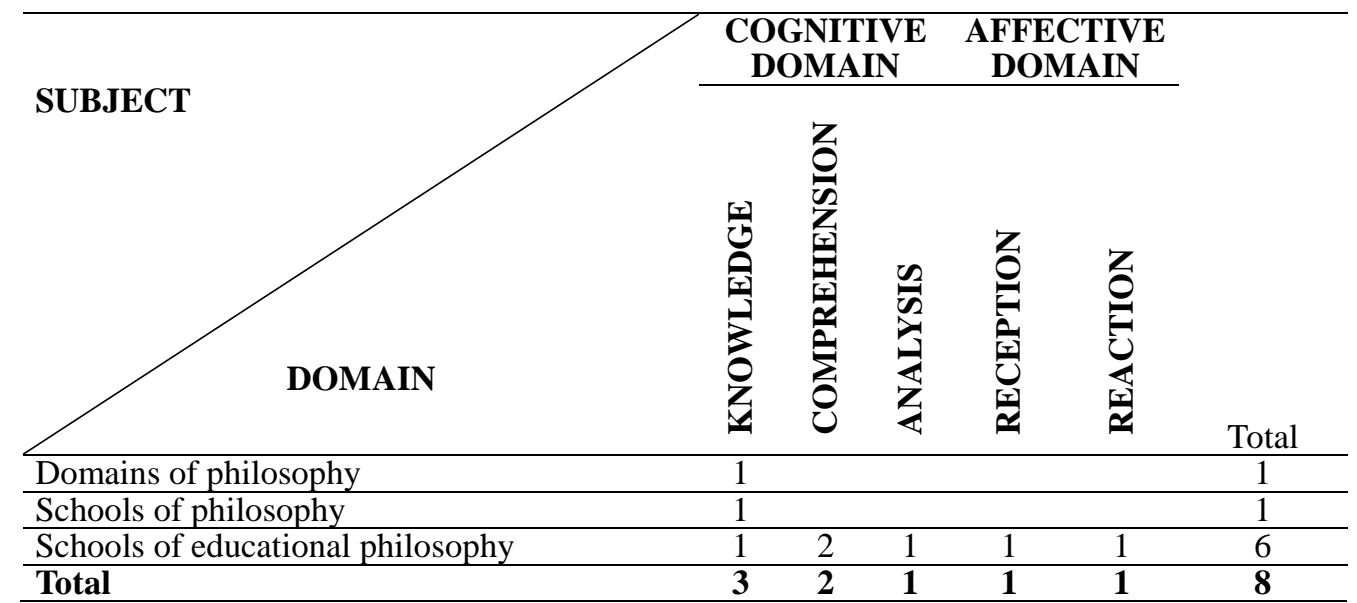


Goals:

1- Knows about curriculum design models.

2- Comprehends the relationship between curriculum design and educational philosophy

3- Explains educational philosophy influencing a design sample.

4- Knows about components of curriculum.

5- Explains how components of curriculum are affected by educational philosophy.

6- Analyses components of curriculum through educational philosophy that affects it.

7- Analyses curriculum that he or she receives in terms of schools of philosophy and educational philosophy.

8- Analyses education systems of countries in terms of social life and philosophy of these countries.

Unit 3: Philosophy and Curriculums

- Curriculum Design Models in Education and Educational Philosophy

Subject-Centred Designs- Learner-Centred Designs, Question-Centred Designs and Philosophy

- The Components of Curriculum and the Effect of Educational Philosophy

Goal-Content-Education Status-Testing Status and Philosophy

Table 4. Unit 3 table of specification

\begin{tabular}{lllll}
\hline & COGNITIVE DOMAIN & Total \\
\hline Curriculum design models & & & \\
\hline Curriculum design models and Educational Philosophy & & 2 & 2 & 4 \\
\hline The Components of Curriculum & 1 & & & 1 \\
\hline The Components of Curriculum and Educational Philosophy & & 2 & & 2 \\
\hline Total & $\mathbf{2}$ & $\mathbf{4}$ & $\mathbf{2}$ & $\mathbf{8}$ \\
\hline
\end{tabular}

Goals:

1- Is aware of how order of seating affects students during education process.

2- Notices about the impacts of student-teacher relations on student life during education process.

3- Notices about the impacts of teachers' methods and techniques on students during education process.

4- Is willing to participate analysis efforts concerning the impacts of education environments on himself.

5- Analyses the impacts of education environments on himself.

6- Establishes relationship between educational strategy, methods and techniques and teacher's educational philosophy.

7- Establishes relationship between order of seating in classroom and teacher's educational philosophy.

8- Establishes relationship between classroom environment and teacher's educational philosophy.

9- Is willing to create education environments in accordance with his or her educational philosophy.

Unit 4: Philosophy and Learning Environments

- Order of sitting and educational philosophy

- Classroom climate and educational philosophy

Student- teacher and student- student interaction

- Methods and techniques of teaching and educational philosophy 
Table 5. Unit 4 Table of Specifications

SUBJECT
DOMAIN

Goals:

1- Remembers basic knowledge about behavioural learning theory.

2- Analyses epistemological bases of behavioural learning theory.

3- Remembers basic knowledge about cognitive learning theory.

4- Analyses epistemological bases of cognitive learning theory.

5- Has knowledge on constructivist paradigm.

6- Explains constructivism as a learning theory.

7- Establishes relationship between constructivist learning and schools of Pragmatism and Progressivism.

Unite 5: Learning Theories and Philosophy

-Behavioralist Learning Theory and Epistemological Bases

-Gestalt Theory- Cognitivists and Epistemological Bases

-Constructivism and Epistemological Bases

Table 6. Unit 5 table of specifications

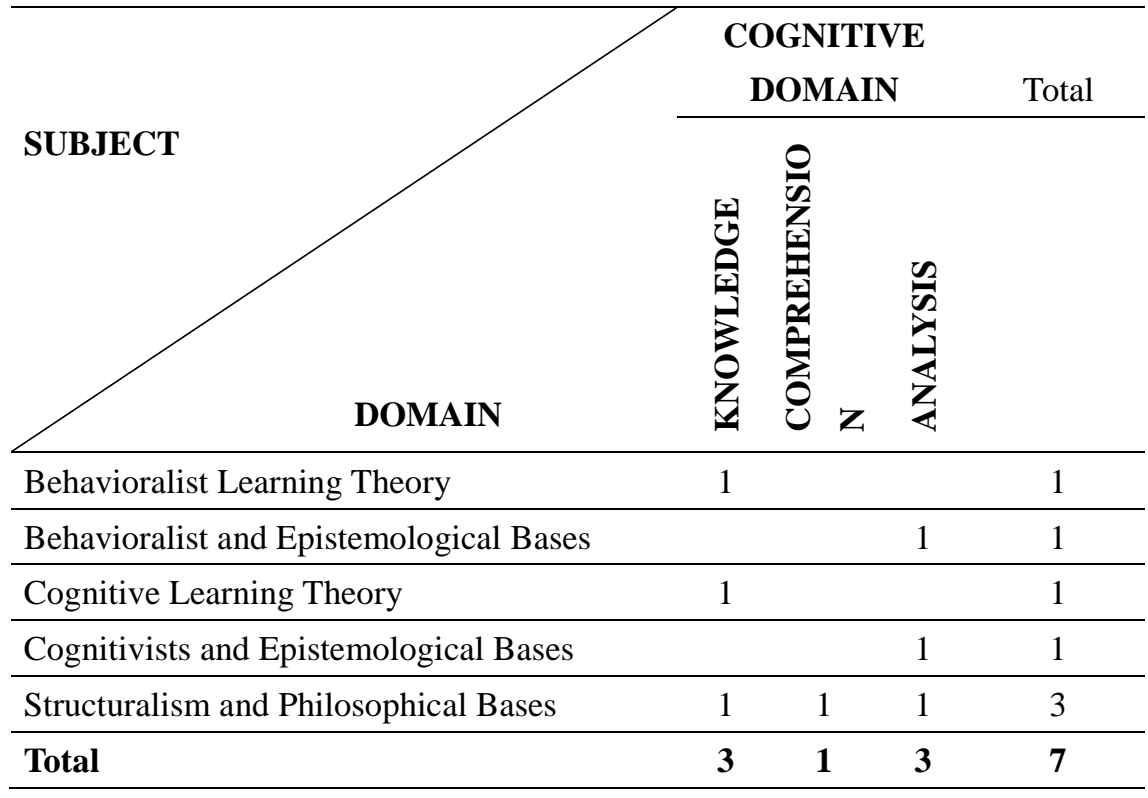


THEME 2: Critical Pedagogy

Goals:

1- Gives examples about the social role of school.

2- Classifies school according to its social role.

3- Is willing to design a school that he or she wants to work.

4- Designs a new school model

Unit 6: School and Life

- Traditional School and Life

- Alternative School

School as a Model of Society

Societal School

Table 7. Unit 6 table of specifications

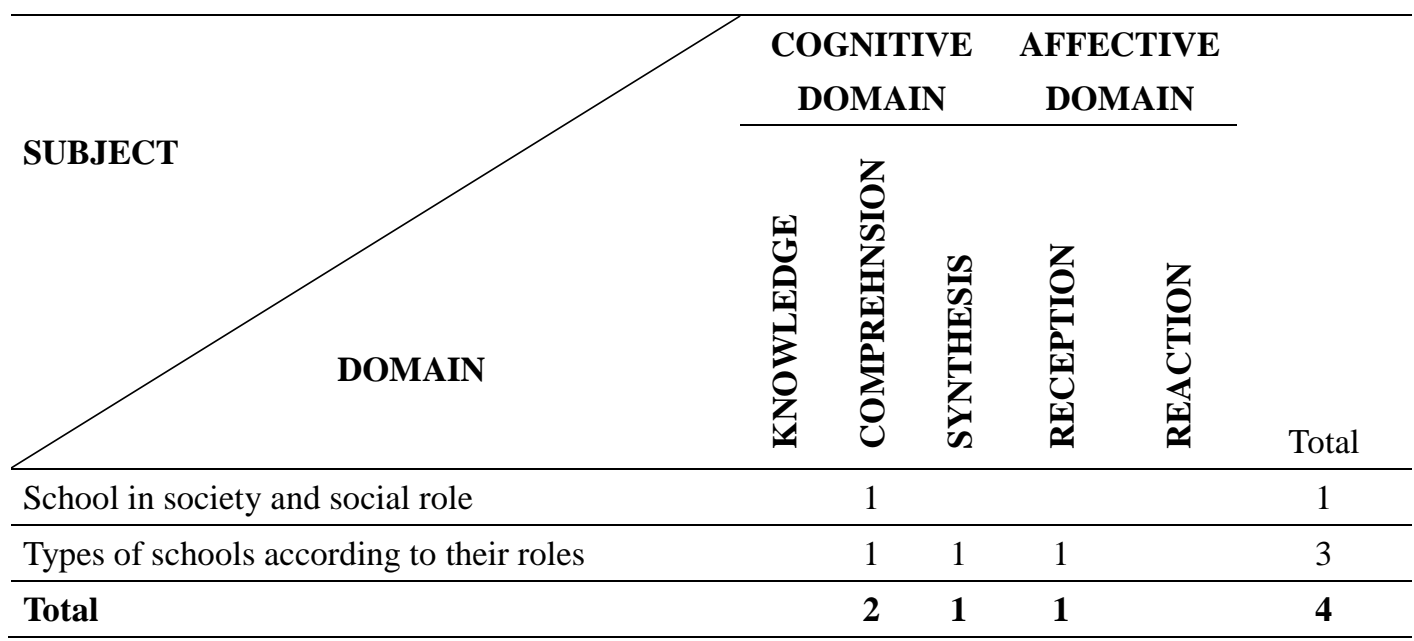

Goals:

1- Explains how education would be possible in a society without schools.

2- Analyses schools of philosophy that education might depend in a society without schools.

3- Analyses educational structure during Seljuk and Ottoman period on the basis of schools of philosophy.

4- Analyses the structure of education in Turkey on the basis of philosophical approaches and in the context of types of schools that he or she studied, courses and curriculums.

Unit 7: Turkish Education System Philosophy and Its Historical Change

- Asian Period Turkish Education and Its Philosophical Base

- Islamic Period Turkish Education and Its Philosophical Base

Seljuks and Ottomans

Anatolian Turkey 
Table 8. Unit 7 Table of Specifications

\begin{tabular}{|c|c|c|c|c|}
\hline \multirow{2}{*}{ SUBJECT } & \multicolumn{3}{|c|}{$\begin{array}{l}\text { COGNITIVE } \\
\text { DOMAIN }\end{array}$} & \multirow[t]{2}{*}{ Total } \\
\hline & 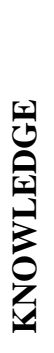 & 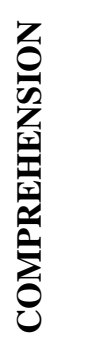 & $\frac{\mathscr{2}}{\bar{Z}}$ & \\
\hline Asian Period Turkish Educational Structure & & 1 & 1 & 2 \\
\hline $\begin{array}{l}\text { Seljuks and Ottoman Period and Turkish Educational } \\
\text { Structure }\end{array}$ & & & 1 & 1 \\
\hline Anatolian Turkey and Turkish Educational Structure & & & 1 & 1 \\
\hline Total & & 1 & 3 & 4 \\
\hline
\end{tabular}

Goals:

1- Is aware of critical attitudes towards education process.

2- Critically evaluates his or her education.

3- Appreciates educational discussion about the ideal education process.

Unite 8: What type of school

Criticism of school

- Ivan Illich - Paulo Friere - Peter McLaren

Table 9. Unit 8 Table of Specifications

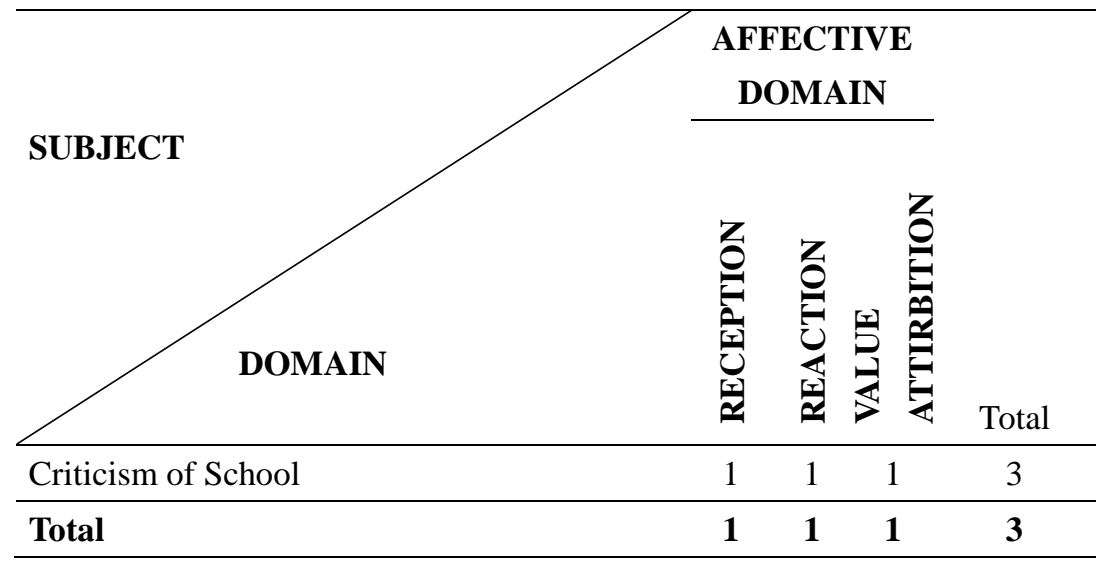

3.5 Selecting and Organizing Learning Experiences

According to Tyler (2013: 284) "if students are not able to transfer their teachings to their lives outside of school, then education is a failure. Generally educators and administrators tend to ignore this important point". In this sense, educational aspects of the design was formed in the way that teachers were able to connect what they learned with the real life. Course planning and learning lives were regulated according to this principle. Needs analysis that was conducted in the early stages of design process, it was observed that candidate teachers' needs towards this course coincided with Tyler's above-mentioned statements.

The process of practice was accomplished through creation of learning environments, which aim to abolish these needs and to include attempts for analysis on the basis of the learned subject, rather than learning it. In such environments, the study benefited mostly from sample cases, method of discussion and academic contradictions in this method, small group discussion and idea production techniques.

Discussions were made in order to enrich learning process, to encourage analytical thinking, for instance about image 
reflections indicating different learning environments, which images reflect whose learning environment, diverse features of these images and the reasons for diversification. Thinking environments were attempted to be created to support analytical efforts of the environments with the help of different sessions including movie sections (Dead Poets' Society, Three Idiots, and Modern Times), conference speeches (Ken Rabinson TED speeches) and caricatures. In the next stages, the analyses were made on how educational philosophies influence learning environments

\subsection{Assessment}

The curriculum of Educational Philosophy Course was developed in a learner-centred design approach and through the Taba Model. After the implementation of this curriculum, it was tested and learners, their changes in their educational ideas and attitudes towards the course were taken into consideration.

It is acknowledge that the changes in educational ideas and attitudes of teacher candidates towards the course would reflect the success of the curriculum. Data analysis results for assessment of the design produced these results:

First of all, the impacts of curriculum design about the Educational Philosophy course on general attitudes of participant learners towards the course are demonstrated. The results are shown on Table 10.

Table 10. The Change of General Attitudes of Participants towards the Course

\begin{tabular}{lccccc}
\hline General Attitude & $\mathbf{N}$ & $\bar{X}$ & $\mathbf{S s}$ & $\mathbf{t}$ & \multirow{2}{*}{$\mathbf{p}^{*}$} \\
\hline First attitude & 112 & 27.8 & 7.18 & \multirow{2}{*}{16.28} & $.000^{*}$ \\
\hline Last attitude & 112 & 40.33 & 2.22 & & \\
\hline
\end{tabular}

$* \mathrm{p}<.05$

As the analysis results indicate on Table 11, curriculum design for the Educational Philosophy course significantly and positively affected general attitudes of participant learned $(\mathrm{p}<.05)$. The following presents the scores of participants from sub-dimensions of the attitude scale, interest in course, anxiety and impacts of the course on professional gains.

Table 11. The Changes of Participants' Attitudes towards the Course in Terms of Interest in Course, Anxiety and Professional Gains

\begin{tabular}{|c|c|c|c|c|c|}
\hline Interest in course & $\mathbf{N}$ & $\bar{X}$ & Ss & $\mathbf{t}$ & $\mathbf{p}^{*}$ \\
\hline First attitude & 112 & 13.04 & 3.8 & \multirow{2}{*}{17.46} & \multirow{2}{*}{$.000^{*}$} \\
\hline Last attitude & 112 & 20.27 & 1.32 & & \\
\hline Anxiety & $\mathbf{N}$ & $\bar{X}$ & Ss & $\mathbf{t}$ & $\mathbf{p}^{*}$ \\
\hline First attitude & 112 & 14.16 & 1.18 & \multirow{2}{*}{11.97} & \multirow{2}{*}{$.000^{*}$} \\
\hline Last attitude & 112 & 10.31 & 3.05 & & \\
\hline Professional gains & $\mathbf{N}$ & $\bar{X}$ & Ss & $\mathbf{t}$ & $\mathbf{p}^{*}$ \\
\hline First attitude & 112 & 4.44 & 1.38 & \multirow{2}{*}{9.88} & \multirow{2}{*}{$.000 *$} \\
\hline Last attitude & 112 & 5.91 & .32 & & \\
\hline
\end{tabular}

$* \mathrm{p}<.05$

As the analysis results indicate on Table 11, curriculum designed for the Educational Philosophy course changed interests of the participant learners significantly and positively $(\mathrm{p}<.05)$. In addition, it decreased the anxiety of the participant learners significantly and positively $(\mathrm{p}<.05)$. The curriculum designed for the study changed the beliefs of the participant learners significantly and positively $(\mathrm{p}<.05)$ that they would use these common course standards in their teaching.

Data analysis results concerning the impacts of designed curriculum on educational ideas of participant learners are presented on the tables below. Table 12 demonstrates scores of participants from the traditional philosophy dimension of the scale. 
Table 12. Change of the Traditional Philosophy Scores of Participants

\begin{tabular}{|c|c|c|c|c|c|}
\hline Traditional & $\mathbf{N}$ & $\bar{X}$ & Ss & $\mathbf{t}$ & $\mathbf{p}^{*}$ \\
\hline First Educational Idea & 112 & 51.58 & 10.29 & \multirow{2}{*}{22.01} & \multirow{2}{*}{$.000 *$} \\
\hline Last Educational Idea & 112 & 25.54 & 3.94 & & \\
\hline
\end{tabular}

$* \mathrm{p}<.05$

As the analysis results on Table 12 indicate, curriculum designed for the Educational Philosophy course decreased scores of educational ideas of participant learners statistically significant $(\mathrm{p}<.05)$. Table 13 presents scores of participants from the popular philosophy dimension of the scale.

Table 13. Change of the Popular Philosophy Scores of Participants

\begin{tabular}{lccccc}
\hline Popular & $\mathbf{N}$ & $\bar{X}$ & $\mathbf{S s}$ & $\mathbf{t}$ & \multicolumn{1}{c}{$\mathbf{p}^{*}$} \\
\cline { 1 - 5 } First Educational Idea & 112 & 37.91 & 11.18 & \multirow{2}{*}{16.46} & \multirow{2}{*}{$.000^{*}$} \\
\hline Last Educational Idea & 112 & 59.07 & 3.70 & & \\
\hline
\end{tabular}

$* \mathrm{p}<.05$

As the analysis results on Table 13 indicate, curriculum design for the Educational Philosophy course, increased educational idea scores of participant learners in popular category in statistically significant way ( $<<.05)$. In this sense, the curriculum designed for the study made the participant learners get out of traditional [Positivist-Modern] subject- or teacher-centred educational philosophy. The curriculum designed for the study made the participants be familiar with the learner-centred popular-modern [Constructivist] educational philosophy.

\subsection{The Control of the Balance and Sequence}

According to Taba (1962: 378) there should be consistency among the units of the design. This consistence occurs between goal that constitute the design, the subjects determined to achieve goals, the way of content's presentation in order to accomplish goals and relationship between learning environments and components of evaluation that test goal accomplishments. In this current design, the components of curriculum were observed to be lined in a consistent way. The goals of the course were set in accordance with the satisfaction of learners' needs; proper content and proper education status were selected and regulated in order to accomplish goals. The scores of participants from the EDU Scale and attitude scale demonstrated that the design had accomplished its main goal.

According to Lindsey (1973), observation of inconsistencies in a whole consisting of different structures is an apparent danger. Skills, concepts and behaviours are processes to be balanced in teacher training programs. Curriculum developer should pay attention to the forms such as emphasis, balance, context, continuity, internal consistency and integrity. In this point, a developed curriculum should be compatible with other curriculums at the same institution. In Turkey, education programs at education faculties aim to train qualified teachers that are able to execute primary and secondary school curriculums that were redeveloped in 2006 with a constructivist understanding. The current developed program, as Lindsley states, is compatible with curriculums of other courses that are taught at the same faculty.

\section{Conclusion and Discussion}

The Education Philosophy curriculum was design with a learner-centred design approach and employment of the Taba Model. The designed curriculum was applied for 14 weeks. The study looked at whether the current design affect educational ideas of participants and their expectations from the implementation in education environments. The analysis of data presented the following results: (1) The curriculum designed for the study changed the attitudes of learners significantly and positively $(\mathrm{p}<.05)$. (2) The curriculum designed for the study decreased the anxiety of the learners towards the course significantly and positively $(\mathrm{p}<.05)$. (3) The curriculum designed for the study changed the beliefs of the learners significantly and positively that they would use these common course standards in their teaching ( $\mathrm{p}<.05)$. (4) The curriculum designed for the study made the participant learners get out of traditional [Positivist-Modern] subject- or teacher-centred educational philosophy, (5) The curriculum designed for the study made the participants be familiar with the learner-centred popular-modern [Constructivist] educational philosophy.

In this context, at the end of the implementation process, participants' attitudes towards the course changed positively and statistically significantly. The analyses indicated that significant changes occurred in participants' inclinations to learner-centred educational idea and implementations. This last result seems to point out that participants gained clearer understanding towards educational ideas and implementations. 
This study is not a teamwork. However, curriculum development efforts necessitate teamwork. For this reason, this current research has limitations as it is not a teamwork. Nevertheless, as Turgut (1983: 217), also states "in the beginning, each curriculum is hypothetical". Similarly, according to Oliva (1988: 463), "curriculum assessment is more than evaluation of educational goals; it aims to evaluate accesses and relevant fields of curriculum". The Educational Philosophy course, whose details were presented above, is also hypothetical. At the same time, this curriculum was implemented and results were analysed. In this sense, this current study should be regarded as an attempt to create a pioneer framework on this issue, which presents significant data. The most important outcome of the designed curriculum is its contribution to understand how teacher candidates are trained and presentation of knowledge and ideas for them to train their students.

According to Friedenberg (1973: 29), teacher-training program should be prepared in a more proper way for candidate teachers, in which they are able to learn very different contents. Moreover, teacher-training process should also prepare candidates for reasons for school's existence. Teacher training programs should essentially start from implementations towards progressive education. In this context, since 2005 Constructivist [Post positivist - Post modern] understanding has become dominant in curriculums of primary, secondary and high schools. In order to train students in the light of this understanding, implementation of the above-mentioned Educational Philosophy Course is considered to play an important role in enhancing the success of curriculums.

According to Stronge (2002), teachers prepare themselves in the traditional sense with series of course focusing on private content areas such as child development, teaching and assessment techniques, method and material. Nevertheless in recent years, teacher training programs and their benefits have been closely examined. Some certificate programs for teachers or suggestions hindered traditional programs for information transfer and they mostly focus on experience and individualism. These programs focus on how students learn, what their learning needs are and how they attempt to understand individual needs of students and to make use of them for student achievement. Similarly, according to Marsh and Willis (2007: 13), "definition of curriculum includes a change from academic knowledge to general knowledge, from permanent knowledge to uncertain knowledge, from intellectual skills to applicable skills, from course-centred education to student-centred education, from planned activities to unplanned activities and school oriented guidance to learner's individual choices". The Educational Philosophy course at this point appears to be a course with significant function. Because according to Bartlett and Burton (2014), Gosselin (2007), Oancea and Bridges (2009), Orstain and Hunkins (1988) and Winc (2012) the course helps us to understand purpose of schools, which subjects are important and what type of tools and methods are employed. Educational philosophy also helps teachers to understand conceptual discussions on educational philosophy and determine their own paths. The developed curriculum was structured for teachers to satisfy these expectations and it takes their analytic thoughts to the forefront.

\section{References}

Aydın, H. (2012). Felsefi temelleri ışı̆̆ııda yapılandırmacılık. Ankara: Nobel.

Bartlett, S., \& Burton, D. (2014). Introduction to education studies. (Çev.Ed. Birsel Aybek). Ankara: Anı Yayıncılık.

Büyüköztürk, Ş. (2006). Sosyal bilimler için veri analizi el kitabı. Ankara: Pegem.

Demirel Ö. (2012). Eğitimde program geliştirme. Ankara: Pegem.

Friedenberg, E. Z. (1973). "Critique of current practice", New Perspectives on Teacher Education (Ed: D.J. McCarty.), ss. 25-38. Jossey-Bass Publishers: San Francisco

Gosselin, C. (2007). Philosophy and the role of teacher reflections on constructing gender. Educational Foundations, 21(3/4), 39-57.

Karasar, N. (1995). Bilimsel araştırma yöntemi. Ankara: 3A Araştırma Eğitim Danışmanlık.

Kumral, O. (2014). Eğitsel düşünce ve uygulamalar (EDU) ölçeğinin geliştirilmesi: Geçerlik ve güvenirlik çalışması Eğitim Bilimleri Araştırmalart Dergisi - Journal of Educational Sciences Research, 4(2), 131-144. http://dx.doi.org/10.12973/jesr.2014.42.8

Kumral, O. (2015). Pedagojik formasyon eğitimi sertifika programına katılan öğretmen adaylarının eğitim felsefeleri. Ĕ̈itim ve Öğretim Araştırmaları Dergisi, 4(2), 73-80.

Lindsey, M. (1973) "Curricular Developments", New Perspectives on Teacher Education, (Ed: D.J. McCarty.), ss. 178-193. Jossey-Bass Publishers: San Francisco.

Marsh, C. J., \& Willis, G. (2007) Curriculum: Alternative approaches, ongoing issues. Pearson Merrill Prentice Hall: New Jersey.

Murphy, L., Mufti, E., \& Kassem, D. (2009). Educational studies: An introduction. Berkshire: McGraw-Hill. 
Oancea, A., \& Bridges, D. (2009). Philosophy of education in te UK: The historical and contemporary tradition. Oxford Review of Education, 35(5), 553-568. http://dx.doi.org/10.1080/03054980903216291

Oliva, P. F. (1988) Developing the Curriculum, Scott, Foresman and Company: Boston.

Ornstein, A. C., \& Hunkins, F. B. (1988). Curriculum. Foundations, principles and issues. New Jersey: Prentice Hall

Osler, J. E. (2013). The psychological efficacy of education as a science through personal, rofessional, and contextual inquiry of the affective learning domain. Journal on Educational Psychology, 6(4), 36-41.

Seçer, İ. (2013). SPSS ve Lisrel ile pratik veri analizi. Ankara: Anı.

Sönmez, V. (2009). Program geliştirmede öğretmen el kitabı. Ankara: Anı Yayıncılık

Stronge, J. H. (2002) Qualities of effective teachers. Association for Supervision and Curriculum Development (ASCD): Virginia

Taba, H. (1962). Curriculum development. New York: Harcourt, Brace \& World, Inc.

Turgut, M. F. (1983) "Program Değerlendirme”, Cumhuriyet Döneminde Eğitim, s: 215-234. Milli Eğitim Basımevi: İstanbul.

Tyler, R.W. (2013). Program geliştirmede spesifik yaklaşımlar (Çev: Abdulkadir Çekin) Insan ve Toplum Bilimleri Araştırmaları Dergisi, 2(2), 270-288.

Varış, F. (1996) Ĕgitimde program geliştirme, Ankara: Alkım Yayınevi.

Weber, A. (1998). Felsefe tarihi (çev, H.V. Eralp) İstanbul: Sosyal Yayınlar

Winch, C. (2012). For philosophy of education in teacher education. Oxford Review of Education, 38(3), $305-322$. http://dx.doi.org/10.1080/03054985.2012.693299

YÖK. (2007) Öğretmen yetiştirme ve eğitim fakülteleri, Yükseköğretim Kurulu Yayını: Ankara.

Yüksel, S. (2012). Eğitim bilimlerinde paradigmatik dönüşüm: Yeni arayış ve yönelimler. Öğretmen Ĕgitimi ve Eğitimcileri Dergisi, 1(1), 35-58.

Zierer, K. (2009). On the historical oblivion of August Hermann Niemeyer, a classic author on education. The Journal of Educational Thought 43(3), 197-222.

\section{$(\mathrm{oc}) \mathrm{BY}$}

This work is licensed under a Creative Commons Attribution 3.0 License. 